\title{
Effect of Different Crop Establishment Methods on Yield Attributes, Yield and Economics
}

\author{
U. Nagabhushanam ${ }^{1}$ and P. Spandana Bhatt ${ }^{2}$ \\ ${ }^{1}$ Regional Agricultural Research Station, Warangal, India \\ ${ }^{2}$ Rice Research Centre, Rajendranagar, Hyderabad, India \\ *Corresponding author
}

\section{A B S T R A C T}

\section{Keywords}

Rice, Crop establishment methods, Grain yield

\section{Article Info}

Accepted:

15 April 2020

Available Online:

10 May 2020
Afield experiment was conducted to study the Effect of different crop establishment methods on yield attributes, yield and economics of rice (Oryza sativa L.,) during Kharif, 2017 at Rice Research Centre, Agricultural Research Institute, Rajendranagar, Hyderabad. The experiment was laid out in Randomized complete block design with four replications and five treatments viz., $\mathrm{T}_{1^{-}}$Machine transplanted rice, $\mathrm{T}_{2^{-}}$Manual transplanted rice in lines, $\mathrm{T}_{3}$ - Manual transplanted rice at random, $\mathrm{T}_{4}-\mathrm{Wet}$ direct seeded rice-drum seeder, $\mathrm{T}_{5^{-}}$Wet direct seeded rice-broadcasting. The results revealed that machine transplanted rice proved to be better for obtaining higher grain yield and net returns as compared to other crop establishment methods.

\section{Introduction}

Rice (Oryza sativa L.,) is one of the most important and widely cultivated cereal crops of the world. Of the total global rice production, $90 \%$ was produced and consumed in Asia and South East Asia. It is not only the staple food for the rice consumption population of Indian sub continent got more than $40 \%$ of caloric requirement from the rice. In India, it is grown on an average of about $44.4 \mathrm{~m}$ ha with a total production of $104 \mathrm{~m} \mathrm{t}$ and productivity of $2.4 \mathrm{t} /$ ha during 2015-16. In Telangana State, rice occupies average of $2 \mathrm{~m}$ ha area and production of 6.62 $\mathrm{m} \mathrm{t}$ with average productivity $3.2 \mathrm{t} / \mathrm{ha}$ (Statistical year book, 2015).

Manual transplanting of the seedlings in to puddle soil is the most common method of rice crop establishment used by the majority of farmers of Asian countries. Mahajan et al., (2013) stated that there was a severe shortage of farm labourers during the peak season of rice transplanting in many rice growing regions of the Asia, which is aggravating the problem for rice transplanting results in delays in transplanting, lower grain yield and delays in sowing/planting of the next crop was observed by Pandey and Velasco (2002). 
Shortage of farm labourers triggers the search for alternative rice crop establishment methods other than conventional transplanting. Machine transplanting is one of the few options available for rice crop establishment method having higher productivity and profitability.

Mechanical rice transplanter is cost effective and operational friendly. It helps in maintaining soil physical properties and productivity point of view. In spite of having knowledge over the traditional transplanting, adoption rate of mechanical transplanters is low due to high initial investment and lack of knowledge in growing mat type nursery. Imparting technical knowledge, ensuring timely availability and encouraging custom hiring may be some of the practical solutions for increasing the rice area under mechanical transplanting. Hence, transplanting of rice seedlings with a suitable mechanical transplanter seems to be most appropriate and promising avenue and alternate crop establishment method, as it minimizes drudgery and saves much of the labour requirement Vasudevan et al., (2014). Keeping in view, the present investigation was carried out for evaluation of rice yield under different crop establishment methods.

\section{Materials and Methods}

A field experiment was carried out during the Kharif, 2017 at Rice Research Centre, Agricultural Research Institute, Professor Jayashankar Telangana State Agricultural University, Rajendranagar, Hyderabad, India to study on "Effect of different crop establishment methods on yield attributes, yield and economics of rice (Oryza sativa L.,)". The experimental site is located at $17^{0}$ $19^{1}$ North latitude and $78^{0} 23^{1}$ East Longitude and $542.6 \mathrm{~m}$ above mean sea level. The composite soil of experimental site is clay loam in texture, low in available N $170 \mathrm{~kg} / \mathrm{ha}$
(Subbaiah and Asija, 1956), high in available P $82 \mathrm{~kg} / \mathrm{ha}$ (Olsen et al., 1954) and available $\mathrm{K} 368 \mathrm{~kg} / \mathrm{ha}\left(1 \mathrm{~N} \mathrm{NH} \mathrm{N}_{4} \mathrm{OAC}\right.$ - extractable $\left.\mathrm{K}\right)$ with neutral in reaction $(\mathrm{pH} 7.3)$ and electrical conductivity $0.26 \mathrm{ds} / \mathrm{m}$.

The experiment was laid out in Randomized complete block design with four replications and five treatments viz., $\mathrm{T}_{1^{-}}$Machine transplanted rice, $\mathrm{T}_{2^{-}}$Manual transplanted rice in lines, $\mathrm{T}_{3}$ - Manual transplanted rice at random, $\mathrm{T}_{4^{-}}$- Wet direct seeded rice-drum seeder, $\mathrm{T}_{5^{-}}$Wet direct seeded ricebroadcasting. The test variety RNR-15048 (Telangana Sona) was soaked on $8^{\text {th }}$ July, incubated on $9^{\text {th }}$ July and sown on $10^{\text {th }}$ July in nursery for $T_{1}, T_{2}, T_{3}$, where as soaked, incubated seeds directly sown in main field for $T_{4}$ and $T_{5}$. The treatment means were compared using least significant difference at 5\% level of significance (Gomez and Gomez, 1984). The economics were also calculated on the basis of cost of cultivation, gross returns, net returns and benefit cost ratio. The cost of cultivation for each treatment was calculated by summing all the variable cost items in the production process. Similarly, gross returns were calculated based on prevailing market price of the produce. The net returns were obtained after deducting the cost of cultivation from gross returns. Thus the benefit cost analysis was obtained by dividing total returns from a unit with total cost of a unit.

\section{Results and Discussion}

\section{Plant population}

Plant population viz., number of hills $/ \mathrm{m}^{2}$ was influenced significantly by crop establishment methods. The plants were spaced at specific distance in $\mathrm{T}_{1-} 30 \times 12 \mathrm{~cm}$ in machine transplanting $\left(28.2 \mathrm{hills} / \mathrm{m}^{2}\right)$ and $\mathrm{T}_{2}-15 \times 15 \mathrm{~cm}$ in manual transplanted rice in lines (42 hills $/ \mathrm{m}^{2}$ ) and $\mathrm{T}_{4^{-}}-25 \times 10 \mathrm{~cm}$ in Wet direct 
seeded rice-drum seeder where as in $\mathrm{T}_{5^{-}}$ soaked, incubated seeds were sown by broadcasting without proper spacing. Manual transplanted rice in lines recorded significantly higher plant population (38 hills $/ \mathrm{m}^{2}$ ) as compared to all other crop establishment methods, as it is spaced both inter and intra row space at $15 \mathrm{~cm}$ and it is comparable with $\mathrm{T}_{5^{-}}$-Wet direct seeded ricebroadcasting (36.2 hills $\left./ \mathrm{m}^{2}\right)$ and lower plant population was recorded in $\mathrm{T}_{1^{-}}$Machine transplanted rice $\left(28.2\right.$ hills $\left./ \mathrm{m}^{2}\right)$ as it is having inter row space $30 \mathrm{~cm}$, intra row space $10 \mathrm{~cm}$. (Table 1).

\section{Plant height}

Plant height was not influenced significantly by crop establishment methods. Similar plant height was observed in all the crop establishment methods.

\section{Days to $50 \%$ flowering}

Days to $50 \%$ flowering was influenced significantly by crop establishment methods. Machine transplanted rice taken significantly higher number of days to $50 \%$ flowering as compared to wet direct seeded rice either by drum seeder or broadcasting and manual transplanted rice at random, it remained comparable with manual transplanted rice in lines. 17 and 25 days age seedlings were raised in mat nursery and nursery for machine transplanted rice, manual transplanted rice in lines respectively, transplanted in the main field. Hence, they took more number of days to $50 \%$ flowering, where as in wet direct seeded rice- broad casting method soaked and incubated seeds was sown directly in the main field, days to $50 \%$ flowering was reduced as there was no raising of nursery (Table 1).

Number of tillers $/ \mathrm{m}^{2}$

Number of tillers $/ \mathrm{m}^{2}$ was influenced significantly by crop establishment methods. Manual transplanted rice in lines recorded significantly higher number of tillers $/ \mathrm{m}^{2}$ (425.2) over all other crop establishment methods; it remained at par with wet direct seeded rice-broadcasting (387.7). Lower number of tillers $/ \mathrm{m}^{2}$ was recorded in Machine transplanted rice (340.5) (Table 1).

Number of tillers $/ \mathrm{m}^{2}$ was significantly higher because of the reason that plants were spaced at specific distance and the competition between the plants was minimum for efficient utilization of all the available resources, there by better translocation of photosynthates from source to sink in manual transplanted rice in lines.

\section{Number of panicles $/ \mathrm{m}^{2}$}

Number of panicles $/ \mathrm{m}^{2}$ was influenced significantly by crop establishment methods. Manual transplanted rice recorded significantly higher number of tillers $/ \mathrm{m}^{2}$ (382.2) as compared to wet direct seeded ricedrum seeder (296.0), manual transplanted rice at random (305.2), it remained comparable with machine transplanted rice (333.2) and wet direct seeded rice-broadcsting (358.0). Lower number of tillers $/ \mathrm{m}^{2}$ was recorded in wet direct seeded rice- drum seeder (296.0) (Table 1).

Number of panicles $/ \mathrm{m}^{2}$ was significantly higher in machine transplanted rice and manual transplanted rice in lines mainly because of optimum plant population, plant geometry coupled with transplanting young seedlings that resulted in even distribution of available resources viz., sun light, moisture, nutrients among rice plants leading to better growth, yield attributes. These results are in corroborate with the findings of Revathi et al., (2016), Pasha et al., (2009) and Ramulu et al., (2019). 
Table.1 Growth parameters, Yield attributes and yield as influenced by different crop establishment methods

\begin{tabular}{|c|c|c|c|c|c|c|c|c|c|c|}
\hline Treatments & $\begin{array}{c}\text { Plant } \\
\text { population }\end{array}$ & $\begin{array}{l}\text { Plant } \\
\text { height } \\
\text { (cm) }\end{array}$ & $\begin{array}{c}\text { Days to } 50 \\
\% \\
\text { flowering }\end{array}$ & $\begin{array}{c}\text { Tillers } \\
\text { (No/m2) }\end{array}$ & $\begin{array}{l}\text { Panicles } \\
\text { (no/m2) }\end{array}$ & $\begin{array}{l}\text { Panicle } \\
\text { length } \\
\text { (cm) }\end{array}$ & $\begin{array}{l}\text { Panicle } \\
\text { weight } \\
\text { (g) }\end{array}$ & $\begin{array}{l}\text { Test } \\
\text { wt. } \\
\text { (g) }\end{array}$ & $\begin{array}{l}\text { Grain } \\
\text { yield } \\
\text { (kg/ha) }\end{array}$ & $\begin{array}{c}\text { Straw } \\
\text { yield } \\
\text { (kg/ha) }\end{array}$ \\
\hline $\begin{array}{l}\text { Mechanized } \\
\text { transplanting }\end{array}$ & 28.2 & 100.5 & 91.3 & 359.5 & 333.2 & 28.4 & 4.0 & 12.1 & 8161 & 9771 \\
\hline $\begin{array}{l}\text { Manual } \\
\text { transplanted } \\
\text { rice in lines }\end{array}$ & 38.0 & 101.5 & 91.3 & 425.2 & 382.2 & 27.7 & 3.8 & 12.0 & 7949 & 9508 \\
\hline $\begin{array}{l}\text { Manual } \\
\text { transplanted } \\
\text { rice at random }\end{array}$ & 30.7 & 100.5 & 87.3 & 346.7 & 305.2 & 27.5 & 3.5 & 11.7 & 7314 & 9363 \\
\hline $\begin{array}{l}\text { Wet direct } \\
\text { seeded rice - } \\
\text { drum seeder }\end{array}$ & 30.0 & 99.5 & 87.3 & 340.5 & 296.0 & 26.6 & 3.2 & 11.7 & 5952 & 7601 \\
\hline $\begin{array}{l}\text { Wet direct } \\
\text { seeded rice - } \\
\text { broadcasting }\end{array}$ & 36.2 & 101.3 & 84.3 & 387.7 & 358.0 & 26.1 & 3.1 & 11.0 & 4478 & 5802 \\
\hline SEm \pm & 2.26 & 0.96 & 0.26 & 15.88 & 296.0 & 0.25 & 0.21 & 0.23 & 242.38 & 283.53 \\
\hline$C D(p=0.05)$ & 7.04 & NS & 0.80 & 49.49 & 51.98 & 0.79 & NS & NS & 755.14 & 883.33 \\
\hline
\end{tabular}


Table.2 Economics as influenced by crop establishment methods

\begin{tabular}{|l|c|c|c|c|}
\hline Treatments & $\begin{array}{c}\text { Cost of } \\
\text { cultivation/ha }\end{array}$ & Gross returns/ha & Net returns/ha & B:C \\
\hline $\begin{array}{l}\text { Mechanized } \\
\text { transplanting }\end{array}$ & 55,000 & $1,36,275$ & 81,275 & 1.48 \\
\hline $\begin{array}{l}\text { Manual transplanted } \\
\text { rice in lines }\end{array}$ & 54,800 & $1,32,718$ & 77,918 & 1.42 \\
\hline $\begin{array}{l}\text { Manual transplanted } \\
\text { rice at random }\end{array}$ & 53,000 & $1,22,742$ & 69,242 & 1.29 \\
\hline $\begin{array}{l}\text { Wet direct seeded - } \\
\text { drum seeder }\end{array}$ & 51,500 & 99,869 & 48,369 & 0.94 \\
\hline & 48,000 & 75,215 & 27,215 & 0.57 \\
\hline $\begin{array}{l}\text { Wet direct seeded rice } \\
\text { - broadcasting }\end{array}$ & & & & \\
\hline
\end{tabular}

\section{Panicle length}

Panicle length influenced significantly by crop establishment methods. Machine transplanted rice recorded significantly higher panicle length $(28.4 \mathrm{~cm})$ as compared to direct seeded rice either by drum seeder or broadcasting; it remained at par with manual transplanting in lines $(27.5 \mathrm{~cm})$ or at random $(27.5 \mathrm{~cm})$. Lower panicle length was recorded in wet direct seeded rice-broadcasting (26.1 $\mathrm{cm}$ ). (Table 1).The significant improvement in panicle length might be due to lower competition for available resources space, sunlight, moisture, nutrients etc. Similar results were also reported by Kumhar et al., (2016).

\section{Panicle weight}

Panicle weight did not influence significantly by crop establishment methods. Machine transplanted rice recorded marginally higher panicle weight $(4.0 \mathrm{~g})$ as compared to all other crop establishment methods; Lower panicle weight $(3.1 \mathrm{~g})$ was recorded in wet direct seeded rice-broadcasting.

The higher panicle weight in machine transplanting might be due to lower competition for available resources i.e., space, 
sun light, moisture, nutrients etc. Similar results were also reported by Kumhar et al., (2016).

\section{Test weight}

Test weight though did not influence significantly by crop establishment methods, machine transplanted rice recorded substantially higher test weight $(12.1 \mathrm{~g})$ followed by manual transplanted rice lines $(12.0 \mathrm{~g})$ (Table 1). These results were also reported by Pasha et al., (2009), Sreenivasulu et al., (2014), Ramulu et al., (2019).

\section{Grain yield}

Grain yield influenced significantly by crop establishment methods. Machine transplanted rice recorded significantly higher grain yield (8161 kg/ha) as compared to all other crop establishment methods; it remained comparable with manual transplanted rice in lines $(7949 \mathrm{~kg} / \mathrm{ha})$. Lower grain yield was recorded in wet direct seeded ricebroadcasting (4478 kg/ha).

Higher grain yield in machine transplanted rice was mainly due to better vegetative growth, dry matter accumulation and effective partitioning to the panicles resulting in more number of panicles $/ \mathrm{m}^{2}$, higher test weight which ultimately improved grain yield. The increase in grain yield of rice in machine transplanting was in agreement with the results reported by Revathi et al., (2016), Satish et al., (2016) and Ramulu et al., (2019).

\section{Straw yield}

Straw yield was influenced significantly by crop establishment methods. Machine transplanting recorded significantly higher straw yield (9771 kg/ha) as compared to wet direct seeded rice either by drum seeder (7601 $\mathrm{kg} / \mathrm{ha})$ or broad casting $(5802 \mathrm{~kg} / \mathrm{ha})$, it remained comparable with manual transplanted rice in lines $(9508 \mathrm{~kg} / \mathrm{ha})$ or at random $(9363 \mathrm{~kg} / \mathrm{ha})$. Higher straw yield in machine transplanted rice was mainly because of better establishment of seedlings, increased vegetative growth, higher dry matter accumulation, effective partitioning and more number of tillers $/ \mathrm{m}^{2}$ which ultimately improved the straw yield. Similar results were also reported by Revathi et al., (2016), Satish et al., (2016) and Ramulu et al., (2019).

\section{Economics}

Among the crop establishment methods, lowest cost of cultivation was recorded in wet direct seeded rice-broadcasting (Rs.48, 000). The cost of cultivation was higher in machine transplanted rice (Rs.55, 000) as well as manual transplanted rice in lines (Rs.54, 000). due to raising of nursery on polythene sheet and involvement of more human labour. The net returns (Rs. 81,275) as well as return per rupee invested $(1: 1.48)$ is maximum in machine transplanted rice. The higher yields of grain and straw recorded in machine transplanted rice was the main reason for higher benefit cost ratio though cost of cultivation was higher than manual transplanted rice in lines

On the basis of results obtained from the present investigation, it is concluded that rice is grown mostly through manual transplanting in India, inspite of the fact that manual transplanting is cumbersome practice and requires more labour. The inadequacy of scarce labour coupled with higher wages during the peak period of farm operations, invariably led to delay in transplanting. To overcome this problem, farmers are gradually switching over to alternate crop establishment methods. 
Machine transplanting is an alternate crop establishment method to conventional manual transplanting, as it saves labour, ensures timely transplanting and attains optimum plant population to increasing the productivity and profitability, proved better compared to other crop establishment methods.

\section{References}

Gomez KA, Gomez AA 1984. Statistical Procedures for Agricultural Research, $2^{\text {nd }}$ Edition. John Wiley and Sons. New York.; p:639.

Kumhar BL, Chavan VG, Rajemahadik VA, Kande VM, DHopavkar RV, Ameta HK and Tilekar RN 2016. Effect of different rice establishment methods on growth, yield and different varieties during Kharif season. International Journal of Plant, Animal and Environmental Sciences. 6(2): 127-131.

Mahajan G, Chauhan BS, Gill MS 2013. Dry seeded rice culture in Punjab state of India; Lessons learned from farmers. Field Crop Research. 144; 89-99.

Pandey S and Velasco L 2002. Economics of direct seeding in Asia. Patterns of adoption and research properties in Direct Seeding: Research Strategies and Opportunities. International Rice Research Institute, Los Banos, Philippines; 3-14.

Pasha MDL, Raghu Rami Reddy P, Badru D and Krishna L 2009. Evaluation of different crop establishment techniques in puddle rice (Oryza sativa L.,). The journal of Research Acharya NG Ranga
Agricultural University. 42(2): 13-16.

Ramulu Ch, Raghu Rami Reddy $\mathrm{P}$ and Narsaiah E 2019. Effect of different establishment methods and nitrogen levels on yield attributes, yield, nutrient uptake and economics of rice (Oryza sativa L.,). The journal of Research PJTSAU. 47(3): 27-32.

Revathi P, Suneetha Devi KB, Gopal Reddy B, Praveen Rao V, Padmaja G and Shivashankar A 2016. Influence of planting methods and integrated nutrient management practices on yield attributes, yield and economics of rice (Oryza sativa L.,). The journal of Research PJTSAU. 44(4): 25-32.

Satish A, Raghu Rami Reddy P, Avil Kumar K and Uma Devi M 2016. Dry matter production and nutrient uptake of rice (Oryza sativa L.,). As influenced by systems of rice cultivation and irrigation regimes in puddle soil. The journal of Research PJTSAU. 44(3): 46-49.

Sreenivasulu S, Bala Hussain Reddy P 2014. Effect of mechanized transplanting on yield, yield attributes and economics of rice (Oryza sativa L.,). The journal of Research Acharya NG Ranga Agricultural University. 42(2): 9-12.

Statistical Year Book. 2015. Directorate of Economics and Statistics, Government of Telanagana, Hyderabad.

Vasudevan SN, Basan gouda, Mathad RC, Dodda goudar SR and Shakuntala NM 2014. Standardization of seeding characteristics for paddy transplanter. Journal of Advanced Agricultural Technologies. 1(2); 141-146. 


\section{How to cite this article:}

Nagabhushanam, U. and Spandana Bhatt, P. 2020. Effect of Different Crop Establishment Methods on Yield Attributes, Yield, Nutrient Uptake and Economics. Int.J.Curr.Microbiol.App.Sci. 9(05): 1663-1670. doi: https://doi.org/10.20546/ijcmas.2020.905.187 